\title{
Nascent pre-mRNA transcripts are associated with nuclear regions enriched in splicing factors
}

\author{
Sui Huang and David L. Spector ${ }^{1}$ \\ Cold Spring Harbor Laboratory, Cold Spring Harbor, New York 11724 USA
}

We have used in situ hybridization and immunocytochemistry to compare the nuclear localization of a specific nascent pre-mRNA and the essential non-snRNP splicing factor SC-35. Nascent c-fos transcripts were detected in serum-induced mouse fibroblasts by in situ hybridization with genomic c-fos probes. Prior to serum induction no c-fos RNA is detected, but these transcripts localize to two dots in the interphase nucleus after induction. The time course of appearance of the dots correlates with the previously determined time course of transcriptional activation of the gene. Upon further analysis by confocal laser scanning microscopy, we have determined that the dots extend through the depth of the nucleus, forming paths. By using high-voltage electron microscopy, we have found that the c-fos path extends out and comes into direct contact with the nuclear envelope. We have also compared the localization of c-fos transcripts with the speckled nuclear regions that are enriched in snRNPs and the non-snRNP splicing factor SC-35. Direct observations of three-dimensional rotations have revealed a close association between the c-fos transcripts and the nuclear speckles. This study demonstrates a direct link between specific nascent RNA transcripts and nuclear speckles that are enriched in pre-mRNA splicing factors.

[Key Words: RNA processing; mRNA transport; nuclear organization]

Received August 15, 1991; revised version accepted September 17, 1991.

Pre-mRNA transcripts must be processed and transported to the cytoplasm, where they are translated into proteins. For most RNA polymerase II transcripts such processing includes the addition of a 7-methylguanosine cap structure at the $5^{\prime}$ end of the nascent RNA transcripts, heterogeneous nuclear ribonucleoprotein (hnRNP) assembly, splicing, polyadenylation, and the exchange of hnRNP proteins for messenger ribonucleoproteins (mRNP) (for review, see Krainer and Maniatis 1988; Steitz et al. 1988; Bindereif and Green 1990). Splicing of nuclear pre-mRNA molecules occurs in spliceosomes-macromolecular complexes composed of small nuclear ribonucleoprotein particles (snRNPs), hnRNPs, and other splicing factors (for review, see Krainer and Maniatis 1988; Bindereif and Green 1990).

While the factors and steps involved in pre-mRNA processing have been studied extensively at the biochemical level both in vivo and in vitro, much less information is available about where and when these events take place within the cell nucleus, and the relationship of pre-mRNA processing to nuclear structure and organization. Localization studies with snRNP-specific antibodies (Spector et al. 1983; Reuter et al. 1984; Spector 1984; Nyman et al. 1986; Verheijen et al. 1986; Habets et al. 1989) or antibodies to the essential nonsnRNP splicing factor SC-35 (Fu and Maniatis 1990;

${ }^{1}$ Corresponding author.
Spector et al. 1991) have shown that these splicing factors are concentrated in a speckled nuclear immunostaining pattern that forms a three-dimensional latticework (Spector 1990; Spector et al. 1991). However, an in situ hybridization study with $2^{\prime} \mathrm{O}$-methyl oligonucleotide probes to various specific small nuclear RNAs (snRNAs) has suggested a more restricted distribution of U2, U4/U6, and U5 snRNAs in the nucleoplasm/CarmoFonseca et al. 1991a,b). Recently, we have used the same 2'O-methyl oligonucleotide probes complimentary to U1 or U2 snRNAs and have found a complete colocalization to the speckled pattern upon increasing the time of hybridization (Huang and Spector 1991). Peptide antibodies to U2AF have shown diffuse nuclear staining in addition to three to four foci (Zamore and Green 1991). It is unclear at this time whether the difference in U2AF staining is a reflection of function or of the sensitivities of the respective reagents and/or techniques. A clearer understanding of splicing and nuclear structure will result from elucidation of the relationship of specific premRNA substrates and splicing factors in the same cell.

We have chosen to evaluate c-fos pre-mRNA at the single-cell level because induction of the c-fos gene is well-characterized at the level of transcription. The c-fos gene is highly conserved among vertebrates (Curran et al. 1982), and its protein product serves a role in coupling external stimuli such as mitogens to long-term transcriptional responses, which leads to cell proliferation. The c-fos gene encodes a nuclear protein that forms a 
part of the AP-1 transcription factor complex and is thought to regulate the transcription of a diverse complement of genes associated with cellular growth and differentiation (for review, see Curran and Franza 1988; Sheng and Greenberg 1990). c-fos gene expression is highly inducible throughout the cell cycle (Bravo et al. 1986 ) as a result of a specific transcriptional response to growth factors such as PDGF, TPA, or serum (Greenberg and Ziff 1984; Kruijer et al. 1984; Muller et al. 1984). Biochemical data have shown that c-fos transcription is detectable within $5 \mathrm{~min}$ after serum stimulation in NIH$3 \mathrm{~T} 3$ cells, peaks within $10 \mathrm{~min}$, and returns to basal levels after 30-60 min (Greenberg and Ziff 1984). In addition, preincubation of quiescent cells with the protein synthesis inhibitor anisomycin results in an increase in both the magnitude ( 100-fold) and duration (240 min) of c-fos transcriptional activation, which occurs upon serum stimulation (Greenberg et al. 1986).

In this study we have investigated the three-dimensional distribution of nascent c-fos transcripts within NIH-3T3 cells. The experimental system used allows us to induce c-fos pre-mRNA transcription, follow its pathway through the nucleoplasm, and compare its localization to the localization of bona fide splicing factors within the same cell nucleus. Our studies show that this cellular transcript extends as a "path" from the site of transcription to the nuclear envelope, with which it comes into direct contact. In addition, we demonstrate an association of c-fos transcripts with regions of the cell nucleus that are concentrated in splicing factors, which suggests that these nuclear regions are the sites of premRNA splicing.

\section{Results}

c-fos RNA transcripts are localized to discrete nuclear regions

c-fos RNA transcripts were localized in NIH-3T3 cells by in situ hybridization with nick-translated biotinylated DNA probes. The primary probe is a plasmid containing a 4.4-kb genomic fragment of the mouse c-fos gene, which includes the $5^{\prime}$ - and 3 '-flanking sequences in addition to the entire coding region (Fig. 1). The gene encodes a $3.5-\mathrm{kb}$ pre-mRNA that is spliced to form a $2.2-\mathrm{kb}$ mRNA. The average size of the nick-translated probe ranged from 100 to $300 \mathrm{bp}$. When cells became quiescent by culturing them in serum-free medium for $24 \mathrm{hr}$ there was no detectable c-fos signal in the cell nucleus (Fig. 2b). However, when serum-starved cells were stimulated by the addition of $20 \%$ serum plus anisomycin for 15 min, a hybridization signal of two dots was observed in each nucleus (Fig. 2d). It is interesting to note that the two c-fos alleles are not located next to each other in the interphase nucleus. The intensity of the dots varied from cell to cell, and in many cells one dot appeared brighter and/or larger than the other dot, suggesting a possible differential level of expression of the two c-fos alleles. When cells were treated with the RNA polymerase inhibitor actinomycin D at a concentration of $10 \mu \mathrm{g} / \mathrm{ml}$ for $2 \mathrm{hr}$ prior to serum induction, no signal was detected in the cell nucleus $15 \mathrm{~min}$ after induction (Fig. 2f). This indicated that the signal observed is dependent on the presence of functionally active RNA polymerase II and represents RNA transcripts. To demonstrate that the observed signal is specific for the c-fos transcript we performed hybridization, in serum-stimulated cells, with the vector sequence alone and found no signal (Fig. $2 \mathrm{~h}$ ). This result indicated that the fluorescent dots seen in Figure $2 \mathrm{~d}$ were a result of a specific hybridization to the mouse c-fos probe.

To further confirm that the signals observed in seruminduced cells were RNA transcripts, cells were treated with either RNase A or DNase I prior to in situ hybridization. Serum-stimulated cells incubated with the c-fos probe after RNase A treatment did not show hybridization signal (Fig. 3d) when compared with cells that were not treated with RNase A (Fig. 3b). However, cells pre-

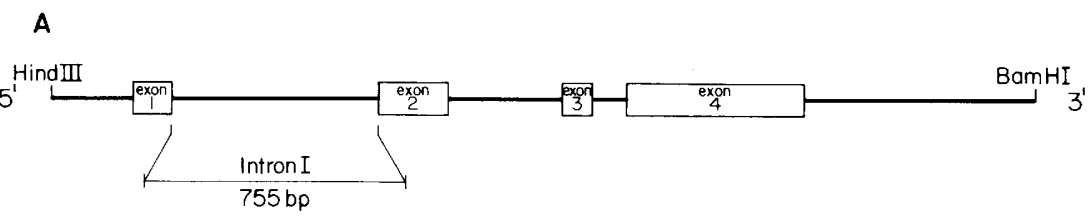

B

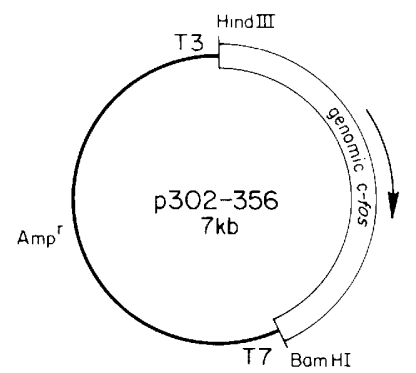

C

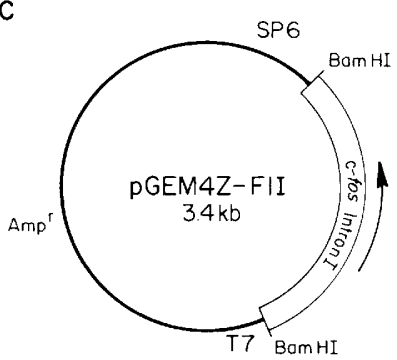

Figure 1. (A) Diagrammatic representation of the mouse c-fos gene. $(B)$ The 4.4-kb c-fos genomic fragment was cloned into the pBS(-) vector (Miller et al. 1984). (C) Intron I $(0.7 \mathrm{~kb})$ was subcloned into the pGEM-4Z vector. 


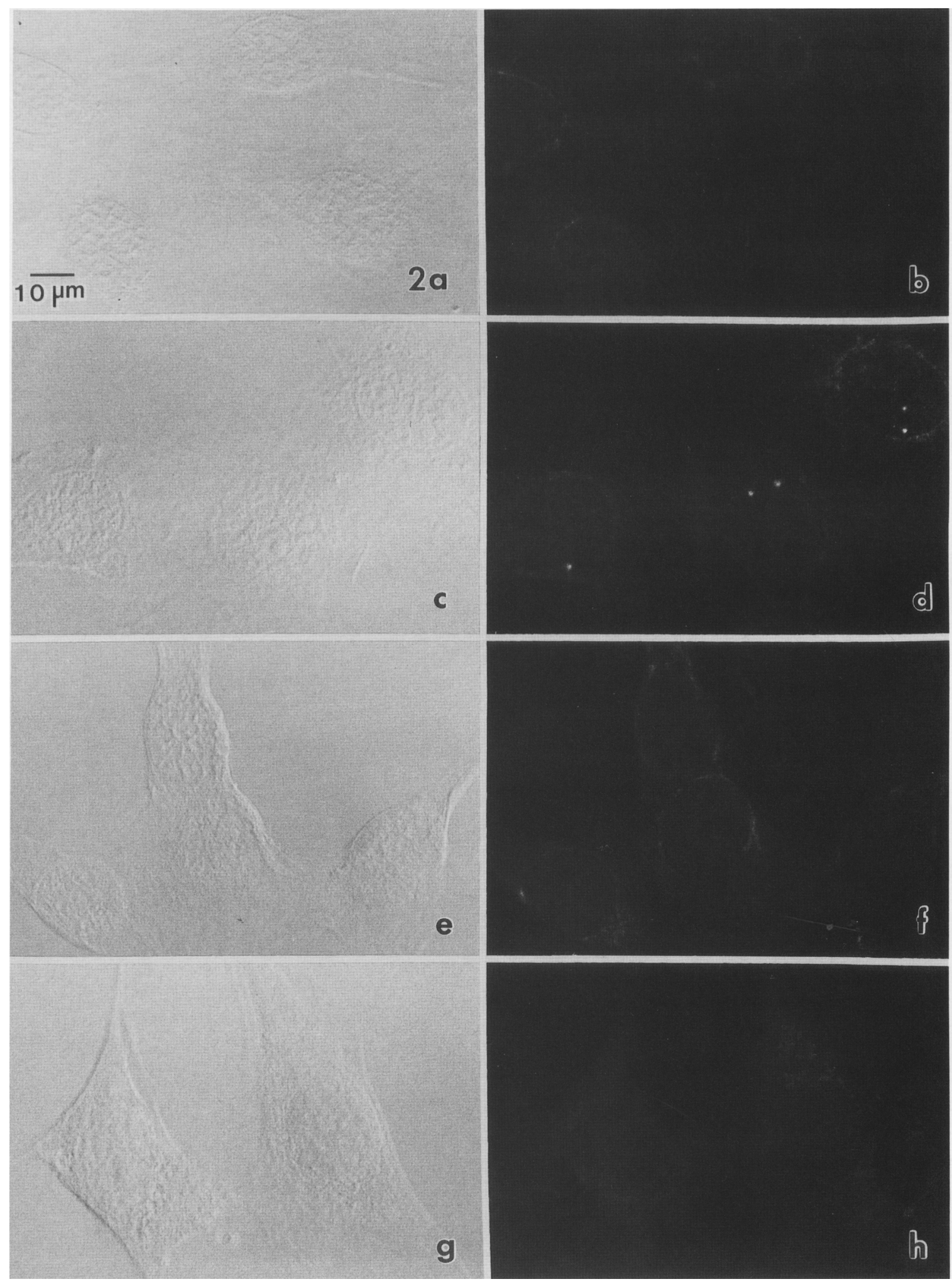

Figure 2. c-fos transcripts are localized to discrete nuclear regions. In situ hybridization with a biotinylated c-fos genomic probe. Cells stimulated with $20 \%$ FCS plus anisomycin for 15 min exhibit two dots in their nuclei $(d)$. Serum-starved cells show no hybridization signal $(b)$. Cells incubated with actinomycin D for $2 \mathrm{hr}$ prior to serum stimulation $(f)$ or hybridized with biotinylated vector sequences minus insert $(h)$ did not exhibit any hybridization signal. $(a, c, e, g)$ Differential interference contrast images of corresponding cells. 

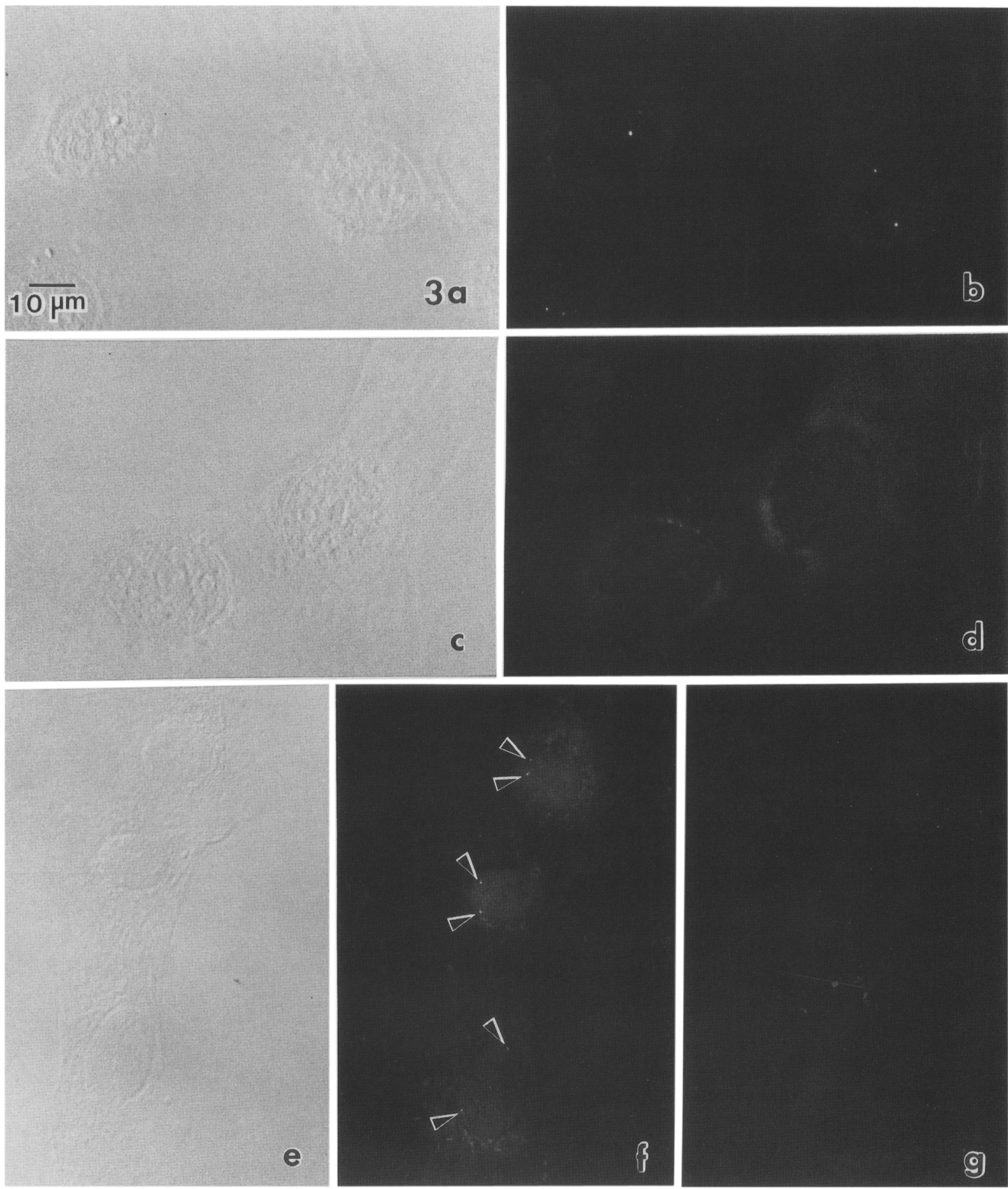

Figure 3. Nuclease sensitivity of transcript localization signal. Cells incubated with RNase A prior to hybridization did not show any specific nuclear staining $(d)$ as compared with cells not treated with RNase A $(b)$. Cells treated with DNase I exhibited a reduced nuclear staining for c-fos transcripts $(f)$. Lack of DAPI staining indicates the complete digestion of DNA in these cells $(g)$. $(a, c, e)$ Differential interference contrast images of corresponding cells.

treated with RNase-free DNase I showed hybridization with the c-fos probe (Fig. 3f). To ensure that the cellular DNA was removed, cells were stained with the DNA fluorophor 4',6-diamidino-2-phenylindole : 2HCl (DAPI).
Cells treated with DNase I prior to hybridization did not exhibit any DAPI staining (Fig. 3g). Although the DNase I treatment did not eliminate hybridization with the c-fos probe, the intensity of the signal was reduced in 
comparison with cells that had not been treated with nuclease (Fig. 3b). Such a reduction in signal intensity could be due to the removal of some of the c-fos transcripts that were attached to the DNA template at the time of DNase treatment. The inducibility of the hybridization signal by serum stimulation, the specificity of the signals to the c-fos genomic probe, the effects of actinomycin D or nuclease treatment on these signals, and the fact that cellular DNA was not made accessible to the probe since it was not denatured confirmed that we were observing the localization of c-fos RNA transcripts.

\section{c-fos transcripts form a path that extends to the nuclear envelope}

While the detection of fluorescent signals by conventional epifluorescence microscopy provides informative data on the distribution of cellular components, a limitation inherent in this approach is that data from threedimensional structures are visualized and recorded in a two-dimensional format. To overcome this shortcoming of conventional epifluorescence microscopy, we analyzed the organization of c-fos transcripts in three-dimensions by confocal laser scanning microscopy. Data to span the depth of the nucleus were compiled from 20-25 optical sections; each section measured $250 \mathrm{~nm}$ in thickness. The stacks of optical sections were reconstructed at $10^{\circ}$ intervals over $360^{\circ}$. Data sets were then examined as $360^{\circ}$ rotations. When reconstructions were examined at $0^{\circ}$ (i.e., no rotation) the transcripts appeared as dots, similar to those observed by conventional epifluorescence microscopy (Fig. 4a,c,e). However, when the reconstructions were rotated $90^{\circ}$, so that the nucleus was observed on its side, the transcripts appeared to extend through the depth of the nucleus, forming a path (Fig. $4 \mathrm{~b}, \mathrm{~d}, \mathrm{f}$ ). The length of the path varied from 0.75 to $1.5 \mu \mathrm{m}$ in distance. The word path represents the elongated distribution of the c-fos transcripts when observed in the $\mathrm{Z}$-axis. We do not imply a predetermined route by the use of this word.

To determine whether the paths of c-fos RNA transcripts extend to the nuclear envelope, we localized c-fos RNA transcripts with a genomic probe by high-voltage $(600 \mathrm{kV})$ electron microscopy. The advantage of this type of microscopy is that thick sections can be examined at high resolution with minimal sample damage by the electron beam. Cells were first hybridized with a biotinylated DNA probe to c-fos RNA that was detected by peroxidase-conjugated avidin. One-micrometer sections were cut in the $\mathrm{Z}$-axis of the cell so that the transcript path could be observed in a single thick section. Analysis of such sections, from six cells examined, confirmed the confocal microscopy data, from $>100$ cells examined, which showed the transcripts to be organized in a path that extended in the depth of the nucleus (Fig. 5). Furthermore, when viewed as stereo pairs (using stereo glasses), the path of c-fos transcripts was observed to extend out and come into direct contact with the nuclear envelope (Fig. 5). Immunoreactivity was also observed in
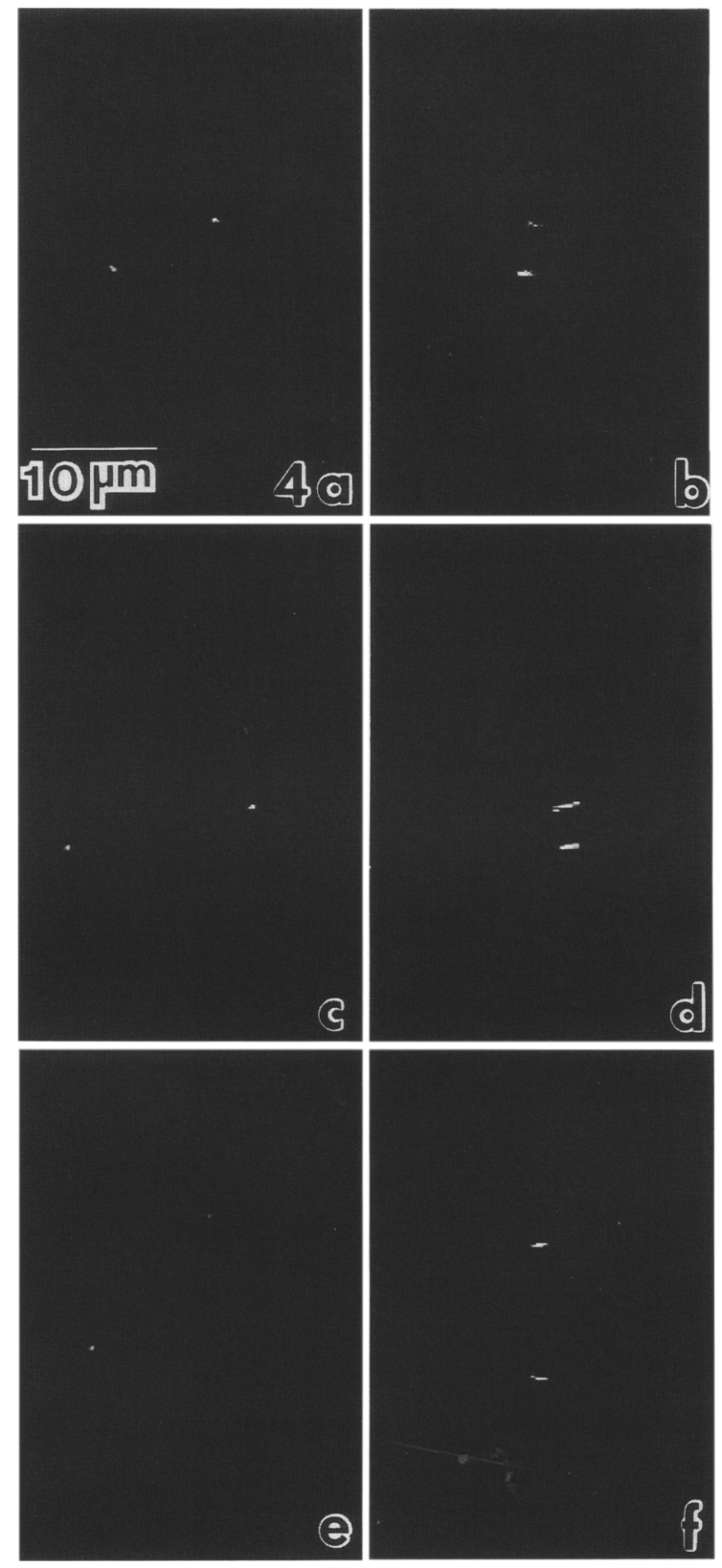

Figure 4. c-fos transcripts form a path through the depth of the nucleus. When three-dimensional reconstructions of optical sections of cell nuclei obtained by confocal laser scanning microscopy were observed at $0^{\circ}$ (no rotation) c-fos transcripts localized as two dots in the interphase nuclei $(a, c, e)$. However, when the nuclei were rotated $90^{\circ}$ the dots appeared as paths that extended $0.75-1.5 \mu \mathrm{m}$ in depth $(b, d, f)$.

the cytoplasm. The cytoplasmic staining occurred on the side of the nucleus where the path of the transcripts exited. We believe that this represented transcripts that had just been transported through the nuclear pores. These results support the hypothesis that c-fos transcripts move in a path from their site of synthesis to the 


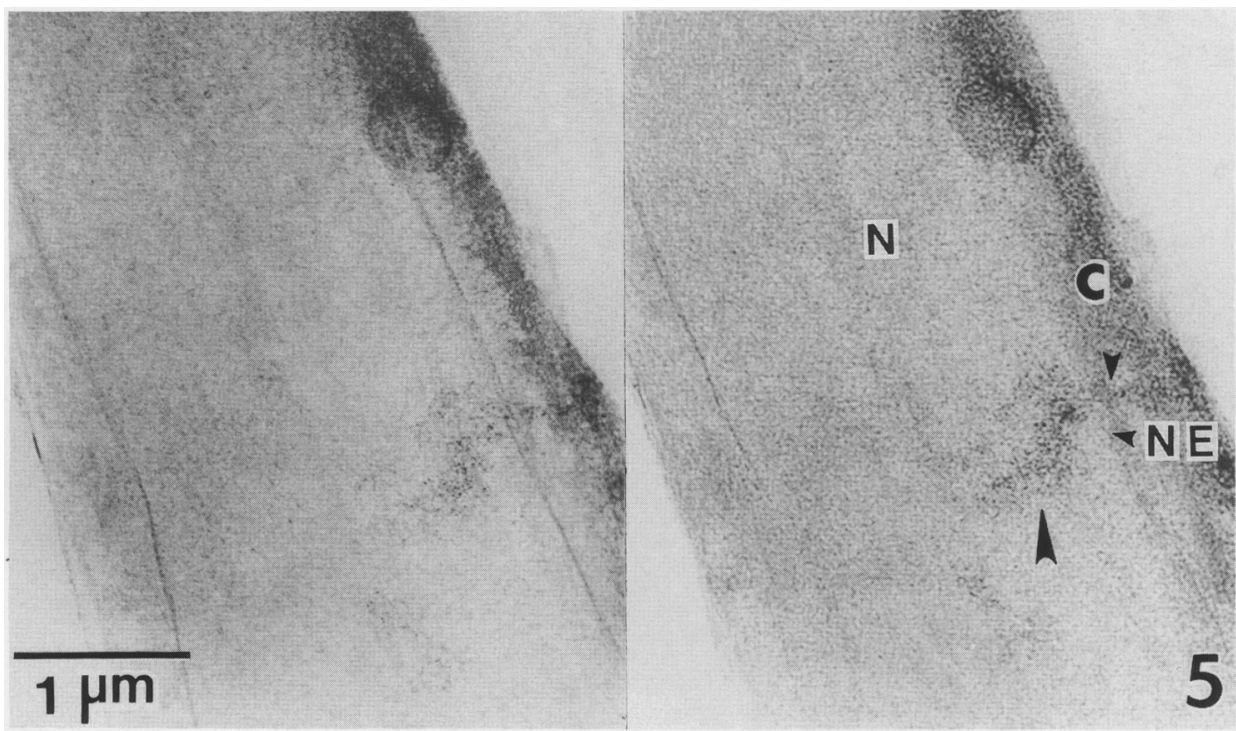

Figure 5. The transcript path extends from the site of transcription to the nuclear envelope. Stereo-pair electron micrograph of a cell cut in cross section, showing the localization of c-fos transcripts visualized by peroxidase-conjugated streptavidin. The $1-\mu m-$ thick section was examined at $600 \mathrm{kV}$ by using a high-voltage electron microscope. The transcript path (large arrowhead) comes into direct contact with the nuclear envelope (NE). The path extends into the cytoplasm (small arrowhead), and transcripts are observed in the cytoplasm $(\mathrm{C})$ on the side of the nucleus $(\mathrm{N})$ where the path of the transcripts exited. Section was not poststained.

nuclear envelope where they enter the cytoplasm as mature mRNP structures.

\section{An intron-specific probe detects unspliced transcripts within the path}

To determine whether c-fos pre-mRNA was a component of the hybridization pattern detected by the genomic clone, we proceeded to localize c-fos pre-mRNA transcripts with an intron-specific probe. A $0.7-\mathrm{kb}$ fragment of the first intron of the c-fos gene was amplified by polymerase chain reaction (PCR) and then subcloned into the pGEM- $4 Z$ vector to generate an intron-specific probe (Fig. Ic). In situ hybridization with this probe produced two fluorescent dots in each cell nucleus (Fig. 6b) similar to those observed by in situ hybridization with the genomic probe (Fig. 6a). However, the intron-specific dots were decreased in intensity. The localization of introns in the transcript-containing dots suggested that these transcripts represented, at least partially, premRNA. To confirm that the probes recognizing genomic or intron-specific sequences of c-fos transcripts localized to the same sites, both probes were used in a double-label experiment. The genomic probe was labeled with biotin11-dUTP and detected by fluorescein-conjugated avidin, and the intron-specific probe was labeled with digoxigenin-11-dUTP and detected by rhodamine-conjugated anti-digoxigenin. When cells labeled in such a manner were examined with different filter combinations, the two dots detected by the genomic probe (Fig. 6c) colocalized with the two dots detected by the intron probe (Fig. 6d). Because cells labeled with each probe separately also resulted in two dots, the colocalization was not due to bleed-through of fluorescent signals. These results confirmed our earlier assumption that the observed localization of c-fos transcripts was in part represented by unspliced c-fos pre-mRNA.

\section{Visualization of $c$-fos transcripts parallels known kinetics of $c$-fos induction}

To examine the timing of the appearance of c-fos transcripts and the movement of these transcripts out of the nucleus, cells hybridized with probe were observed at various times after serum induction. After serum starvation for $24 \mathrm{hr}$, cells were stimulated with $20 \%$ fetal bovine serum (FBS) without anisomycin for 5, 15, 30, 45, and $60 \mathrm{~min}$, hybridized with the c-fos genomic probe, and photographed at the same exposure times to allow a quantitative as well as qualitative examination of the distribution of c-fos transcripts at the cellular level. Anisomycin was not used in this experiment because it prolongs the expression of c-fos transcription. Cells that were serum-starved for $24 \mathrm{hr}$ did not exhibit any c-fos transcripts in their nuclei (Fig. 7a). At 5 min after serum stimulation, $71 \%$ of the cells showed c-fos RNA transcripts (Fig. 8) localized as two dots in each nucleus (Fig. $7 \mathrm{~b})$. In many cases, it was impossible to photograph both dots in a cell population because they were in different focal planes. At $15 \mathrm{~min}$ postserum induction, $92 \%$ of the cells (Fig. 8) expressed c-fos RNA (Fig. 7c). At $15 \mathrm{~min}$ after serum induction, cytoplasmic staining was detectable. This cytoplasmic staining is probably a result of the transport of mRNA into the cytoplasm for translation. Between 30 and $45 \mathrm{~min}$ after serum induction the percentage of cells showing c-fos expression decreased dra- 

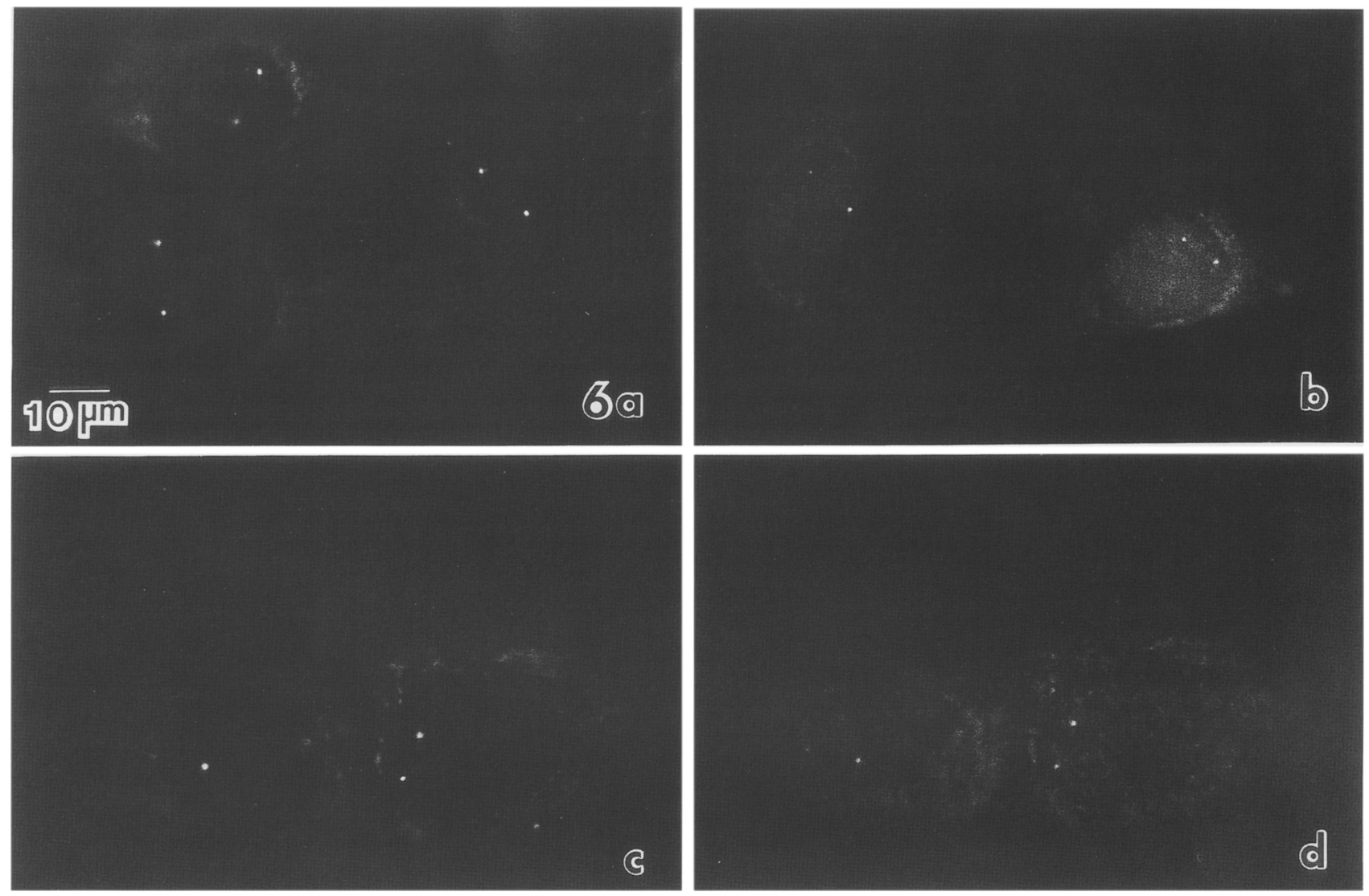

Figure 6. An intron-specific probe detects unspliced transcripts within the path. Unspliced c-fos transcripts were localized with a $0.7-\mathrm{kb}$ intron-specific probe $|b|$. The localization of transcripts with the intron-specific probe appeared to be similar to the localization of c-fos transcripts with the genomic probe $\{a \mid$. Double-labeling with a biotinylated genomic c-fos probe $(c)$ and a digoxigenin-labeled intron-specific probe $(d)$ confirmed the colocalization.

matically from $67 \%$ at $30 \mathrm{~min}$ to $4 \%$ at $60 \mathrm{~min}$ (Fig. 81 , and staining in many cells appeared to be weaker (Fig. $7 \mathrm{~d}, \mathrm{e})$. After $1 \mathrm{hr}$ of serum induction, c-fos RNA was no longer detectable among the majority of cells (Fig. 7f). The time course of c-fos transcriptional induction detected by in situ hybridization at the cellular level is consistent with that described by biochemical assays (Greenberg and Ziff 1984). The fact that not all of the cells were expressing c-fos RNA transcripts at any given time, and that cell-to-cell differences in signal intensity were observed, is representative of the heterogeneity in NIH-3T3 cell populations (Rubin et al. 1990).

To evaluate the distance that the c-fos transcript paths extend through the depth of the nucleus, cells were examined at $5 \mathrm{~min}$ (Fig. 9a-d), $15 \mathrm{~min}$ (Fig. 9e-h), and 30 min (Fig. 9i-1) postserum stimulation. Cells showing both shorter and longer paths of c-fos RNA transcripts were found at each of these time points. However, after 15 min of serum induction-the peak of c-fos transcription-longer paths were observed more commonly than at other time points, and at $30 \mathrm{~min}$ the paths were predominately shorter. The variations observed in the length of the transcript paths suggest that these paths represent a dynamic movement of transcripts from their sites of synthesis toward the nuclear envelope. The variation in the length of the transcript paths between different cells could reflect a difference in the response to serum induction, transcription rate, post-transcriptional modification, and the rate of mRNA transport.

\section{c-fos transcripts associate with nuclear regions} enriched in splicing factors

To determine the three-dimensional relationship of c-fos transcripts to nuclear regions enriched in splicing factors, optical sections were obtained by confocal microscopy from cells that had been hybridized with the genomic c-fos probe and immunocytochemically labeled with an antibody to SC-35, an essential non-snRNP splicing factor (Fu and Maniatis 1990; Spector et al. 1991). SC-35 has been shown to colocalize in speckled nuclear regions with snRNPs (Fu and Maniatis 1990). The three-dimensional images of both c-fos RNA transcripts and SC-35 localization were collected in separate files and superimposed by computer software. The positions of c-fos RNA transcripts and SC-35 were directly compared in rotations at all angles through $360^{\circ}$. Photographs taken from three different cells showing the rela- 

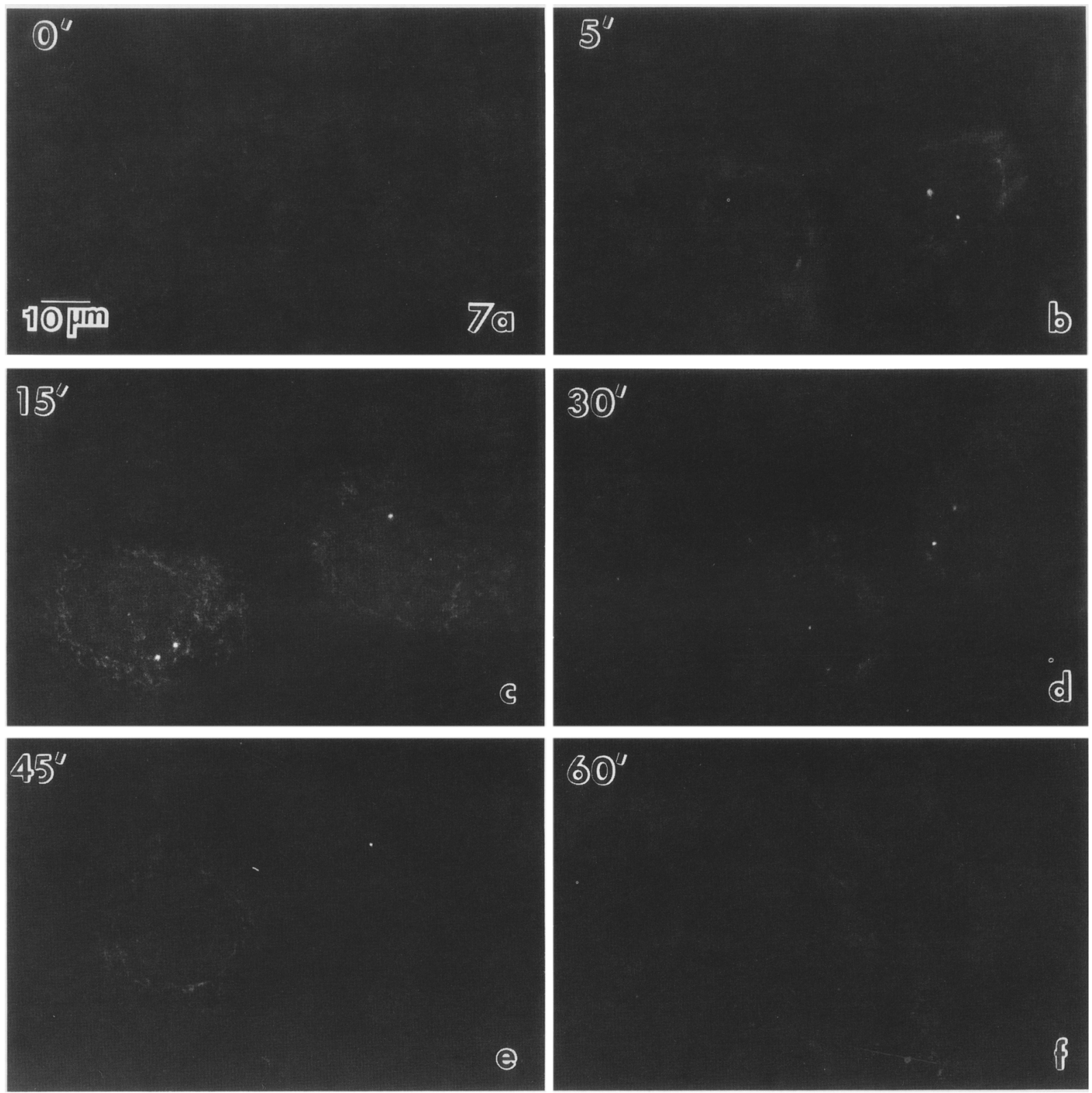

Figure 7. Visualization of c-fos transcripts parallels known kinetics of c-fos induction. The localization of c-fos RNA transcripts was examined at various time points after serum stimulation in the absence of anisomysin. Transcripts were first observed 5 min after stimulation $\langle b|$ and were no longer detectable after $60 \mathrm{~min}$ of serum stimulation $(f)$.

tionship between the c-fos RNA transcripts and SC-35 at $0^{\circ}, 50^{\circ}, 100^{\circ}$, and $150^{\circ}$ of rotation are shown in Figure 10. In all cases (50 cells examined) it is clear that the c-fos RNA transcripts are in extremely close proximity to the location of SC-35. Portions of the c-fos transcripts /yellow regions) appear to wrap around the SC-35 speckles (red regions) in some cells (Fig. 10a,b,f). In other cells, the transcripts appear to extend into speckles (Fig. 10e-l). A complete colocalization between transcripts and speckled nuclear regions was not observed. The partially overlapping pattern of localization of c-fos pre-mRNA and the splicing factor SC-35 provides additional support for the hypothesis that pre-mRNA splicing occurs on the periphery of or adjacent to nuclear speckles. This finding is consistent with previous results that showed $\left[{ }^{3} \mathrm{H}\right] \mathrm{uri}$ dine incorporation sites at the periphery of nuclear speckles (Spector 1990).

\section{Discussion}

In this paper we have reported on the three-dimensional localization of nascent c-fos RNA transcripts in the interphase nucleus of NIH-3T3 cells. As a means of evaluating more closely the relationship of pre-mRNA splic- 


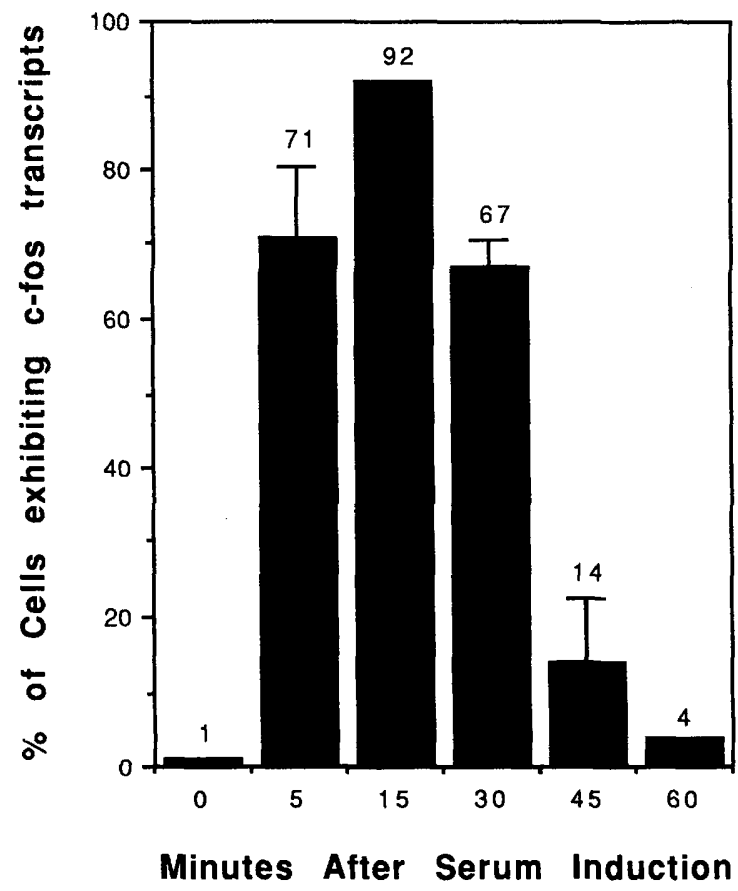

Figure 8. Histogram of the percentage of cells exhibiting detectable c-fos transcripts at indicated times after serum stimulation in the absence of anisomysin. For each time point the first 100 cells observed were counted.

ing to nuclear structure and organization, we analyzed the RNA transcripts of the c-fos gene because their expression can be regulated by serum depletion or stimulation (Greenberg and Ziff 1984; Muller et al. 1984). Using in situ hybridization combined with confocal laser scanning microscopy, we observed c-fos transcripts in the nuclei of cells within 5 min of serum stimulation of quiescent $\mathrm{NIH}-3 \mathrm{~T} 3$ cells, and by $15 \mathrm{~min}$ poststimulation the c-fos signal peaked. Our findings, at the single-cell level, of the transient expression of c-fos transcripts are consistent with previous biochemical studies that evaluated runoff transcripts from nuclei isolated at various time points poststimulation (Greenberg and Ziff 1984). In our experiments, the c-fos transcripts were present as two discrete dots in the nuclei of NIH-3T3 cells. A similar dot-like distribution has been shown for the distribution of string RNA within cells of a cycle-14 Drosophila embryo (O'Farrell et al. 1989). The dots that we observe with the c-fos probe appear to represent transcripts from each of the two c-fos alleles in this cell line. Occasionally, three dots were observed in nuclei (data not shown). Because NIH-3T3 cells are known to spontaneously change ploidy level in culture we attribute the occurrence of a third dot to an additional copy of the c-fos gene in these cells. We interpret the intensely stained dots to represent the active sites of transcription and the localization of transcripts that are still attached to the DNA backbone. This possibility is likely in light of our findings that DNase I digestion decreased the size of the dots. We interpret these results to mean that upon removal of the cellular DNA a subset of the c-fos transcripts that were being transcribed and were therefore still attached to the DNA were removed as well.

When observed in the Z-axis, the c-fos RNA dots were found to be elongated, forming paths that came into direct contact with the nuclear envelope. We propose that the path-like distribution represents the movement of nascent transcripts from the site of transcription to the nuclear envelope. The localization of c-fos nascent RNA transcripts to a path within the interphase nucleus suggests that RNA processing and transport may be spatially organized processes that are dependent on nuclear architecture (for review, see Berezney 1984). Blobel (1985) proposed that the position of chromosomes, transcription, and RNA transport may be under strict regulation in a three-dimensional spatial manner. It was suggested that specific genes are associated with particular nuclear pore complexes and the transcripts produced by that gene are "gated" to exit the nucleus by way of that pore complex. Although our study has not distinguished a direct interaction between the c-fos gene or its product and a specific nuclear pore, our observation of $c$-fos RNA localization would support a basic premise of the genegating hypothesis. That is, specific transcripts reach the nuclear periphery at a very limited area that could be related to a group of nuclear pores rather than a single pore complex. Our observation of the organization of nascent cellular transcripts as a path is consistent with an earlier study (Lawrence et al. 1989) reporting that Epstein-Barr virus (EBV) RNA transcripts in Namalwa cells can be detected as a "track" in the nuclei. The EBV RNA tracks were reported to average $5 \mu \mathrm{m}$ in length. The difference in length between EBV tracks and c-fos paths may be due to differences in cell type, cell preparation methods, distance of the originating gene from the nuclear envelope, or the amount of transcript.

Although export of mRNA from the cell nucleus is a basic biological process required for gene expression, little information on the details of this process is available (for review, see Feldherr and Dworetzky 1988). It has been proposed by Agutter (1988) that mRNA transport is a solid-state process by which mRNA is structurally bound rather than freely soluble before, during, and after movement across the nuclear envelope. Our observation on the localization of $\mathrm{c}$-fos transcripts is consistent with such a model. A path-like distribution of the RNA transcripts indicates that the movement of the RNA transcripts follows a confined route through the nucleus. Such a three-dimensional spatially regulated pathway suggests that the flow of RNA transcripts through the nucleus may be conducted on a solid support rather than in a soluble form that would diffuse in all directions. The solid support in the nucleus may consist of nuclear matrix components. It has been reported that nuclear actin and myosin may be involved in mRNA transport in the nucleus (LeStourgeon 1978; Schindler and Jiang 1986). In addition, splicing factors (Vogelstein and Hunt 1982; Spector et al. 1983), pre-mRNA (Ciejek et al. 1982; Mariman et al. 1982; Xing and Lawrence 1991), and functional spliceosomes (Zeitlin et al. 1989) have been shown 

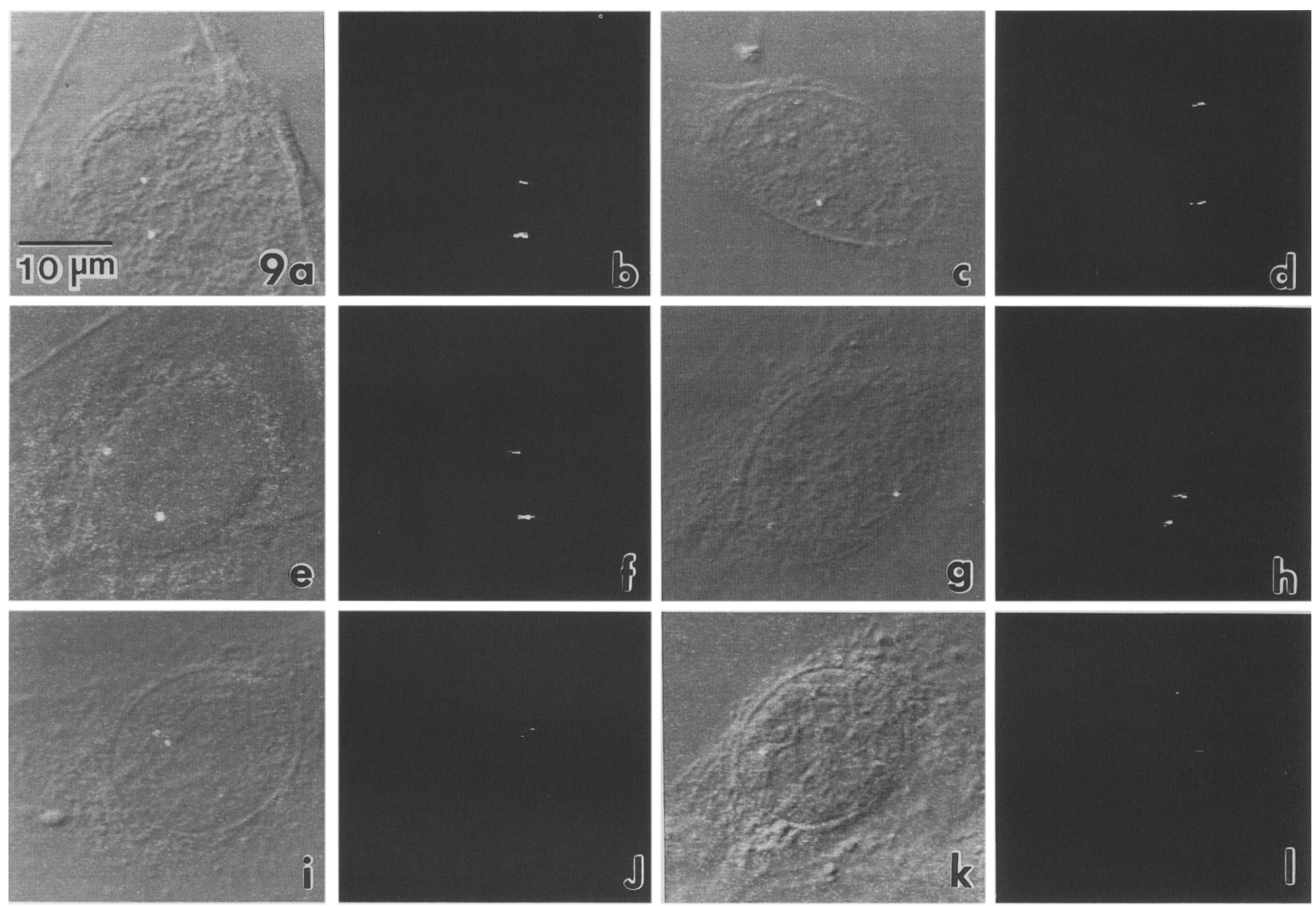

Figure 9. c-fos transcript paths vary in length at different times following serum induction; the longest paths predominate at 15 min postserum induction. Three-dimensional reconstructions of optical sections of cell nuclei were obtained by confocal laser scanning microscopy. The lengths of the c-fos transcript paths were examined at $5 \mathrm{~min}(b, d), 15 \mathrm{~min}(f, h)$, and $30 \mathrm{~min}(j, 1)$ after serum stimulation in the absence of anisomysin. $\{a, c, e, g, i, k)$ Overlays of fluorescent in situ hybridization signals and differential interference contrast images of the same cells at $0^{\circ}$ of rotation. $(b, d, f, h, i, l)$ Fluorescent hybridization signals of the respective cells rotated $90^{\circ}$.

to be associated with the nuclear matrix. These observations suggest that the RNA transcripts and splicing factors, together with some type of nuclear skeleton support, may form a solid but dynamic mesh work, which traverses around the euchromatin-enriched nuclear regions and may be involved in pre-mRNA processing and mRNA transport.

When we compared the localization of c-fos transcripts with the localization of SC-35-an essential splicing factor-we found the transcripts to be in close proximity to a portion of the speckled nuclear regions enriched in SC-35 and snRNPs. The regions enriched in trancripts and splicing factors were observed to be intermingled and/or in the same environs. The possibility that this association is a random event is unlikely in light of the fact that the nuclear speckles were determined to occupy $\sim 17 \%$ of the nuclear volume and the c-fos transcripts occupied $<1 \%$ of the nuclear volume of NIH-3T3 cells. These data are in agreement with that of our previous study in CHOC400 cells, which showed that the speckled pattern occupied $\sim 18 \%$ of the nuclear volume. Furthermore, Wang et al. (1991) showed recently that pre-mRNA microinjected into cell nuclei of living cells localized to the speckled pattern identified by anti-SC-35 or anti-Sm antibodies. These data show that both endogenous and microinjected transcripts are associated with speckled nuclear regions and suggest that these regions may be involved in pre-mRNA processing.

A basic, unanswered question in the fields of RNA processing and nuclear structure has been: What is the spatial relationship of RNA processing to transcription and nuclear structure? Several studies have presented evidence that pre-mRNA splicing occurs cotranscriptionally on the nascent transcripts of early Drosophila embryo genes (Beyer and Osheim 1988), genes in mouse and Drosophila somatic cells (Fakan et al. 1986), as well as puffs and Balbiani rings in Chironomus polytene chromosomes (Sass and Pederson 1984). Electron microscopy studies in mammalian cells have shown that snRNPs (Fakan et al. 1984; Puvion et al. 1984), hnRNP antigens (Fakan et al. 1984), and the non-snRNP splicing factor SC-35 (Spector et al. 1991) localize to nuclear structures 


\section{Huang and Spector}

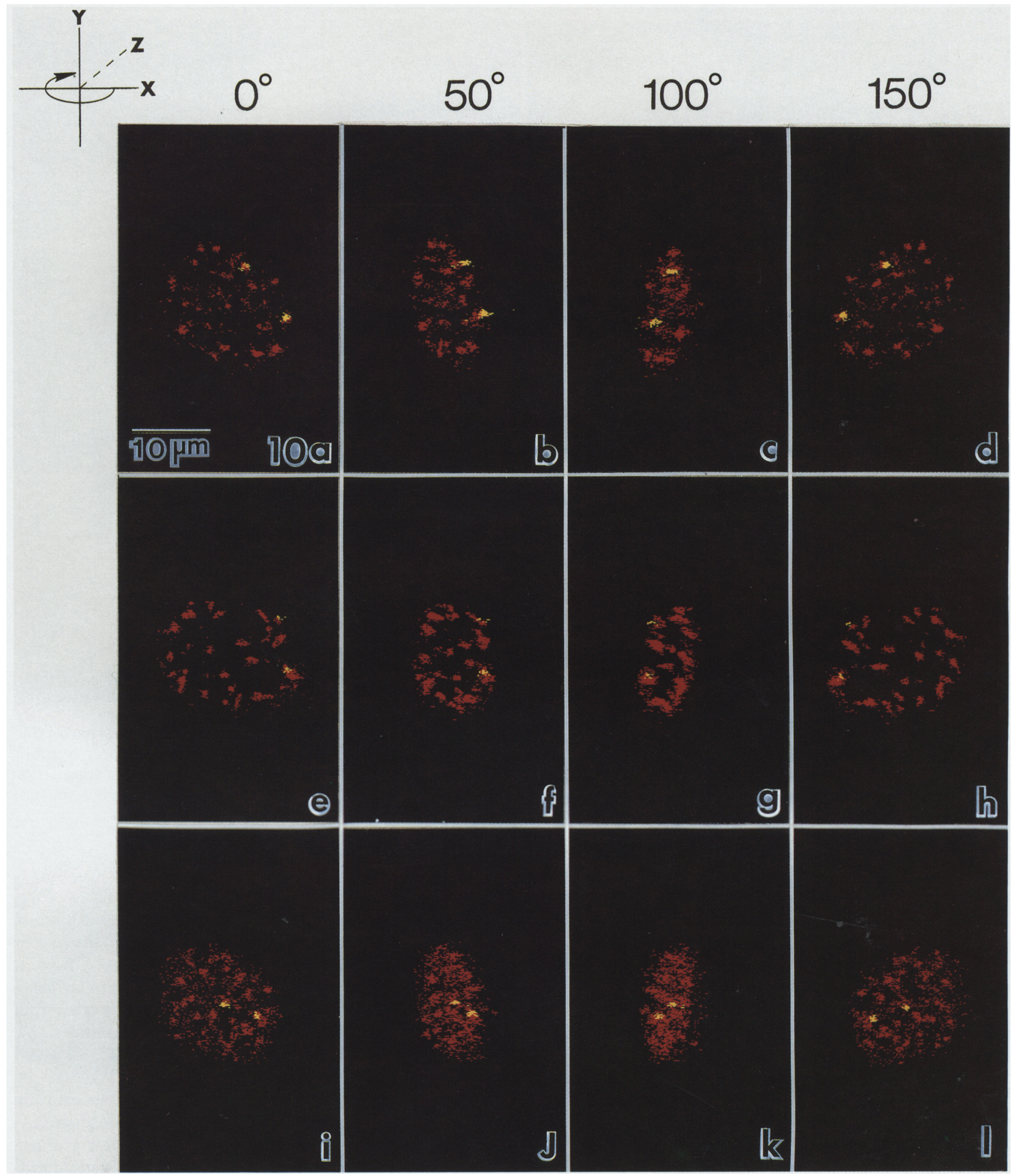

Figure 10. c-fos transcripts are closely associated with nuclear regions enriched in the essential splicing factor SC-35. Cells were hybridized with a biotinylated c-fos genomic probe (yellow regions) and subsequently immunolabeled with anti-SC-35 antibodies (red regions). Three-dimensional reconstructions of optical sections of cell nuclei were obtained by confocal laser scanning microscopy. Three cells are shown at $0^{\circ}, 50^{\circ}, 100^{\circ}$, and $150^{\circ}$ of rotation. (a-d,e-h, and $i-1$ represent three different cells.)

called perichromatin fibrils. These fibrils, which are distributed throughout the nucleus, have been proposed to represent the sites of active transcription on the basis of their heavy labeling with $\left[{ }^{3} \mathrm{H}\right]$ uridine (Bachellerie et al. 
1975; Fakan et al. 1976). These data suggest that splicing components are present at the sites of active transcription.

In addition to staining perichromatin fibrils, snRNPs (Spector et al. 1983; Fakan et al. 1984; Puvion et al. 1984) and SC-35 (Spector et al. 1991) have been shown by immunoelectron microscopy to localize to interchromatin granule clusters. On the basis of fluorescent and electron microscopic staining of snRNPs and SC-35, we deduce that the perichromatin fibrils and interchromatin granules form an interconnected speckled distribution pattern in the interphase nucleus. A ribonucleoprotein network was first described by Smetana et al. (1963) and later elaborated upon by Puvion and Bernhard (1975). We propose that the interchromatin granule-containing portion of the fluorescent staining pattern serves as storage and/or assembly sites for splicing factors. Support for this premise comes from previous in situ autoradiographic studies showing that following $\left[{ }^{3} \mathrm{H}\right]$ uridine incorporation, even after prolonged periods of chase, little to no labeling occurs over interchromatin granule clusters (Fakan and Bernhard 1971,1973; Fakan et al. 1976; Fakan and Nobis 1978). We propose that upon activation of a gene, factors from a nearby interchromatin granule cluster may move to the site of the active gene and associate directly with the nascent transcripts (perichromatin fibrils). Therefore, the speckled staining pattern, observed by immunofluorescence microscopy, represents both the localization of transcripts (perichromatin fibrils) and the localization of storage and/or assembly sites (interchromatin granules). Our results, which show a close association of nascent c-fos transcripts with nuclear speckles, support this hypothesis. Future studies will attempt to elucidate the signals that are responsible for coordinating the efficient movement of splicing factors between storage sites and splicing sites.

Our interpretation of the localization of splicing factors in mammalian cells has some similarities with the organization of splicing factors that has been reported in amphibian germinal vesicles (Gall and Callan 1989; Wu et al. 1991; for review, see Gall 1991). The nascent RNA chains comprising the loops of lampbrush chromosomes have been shown to be uniformly stained with antibodies against hnRNP proteins, snRNPs, and SC-35. Thus, the loops appear to be packaged into a ribonucleoprotein complex that includes all of the components of the spliceosome for which probes are available. This situation would be comparable to the staining of perichromatin fibrils in mammalian cells by anti-snRNP (Fakan et al. 1984; Puvion et al. 1984), anti-hnRNP (Fakan et al. 1984), and anti-SC-35 (Spector et al. 1991) antibodies. Therefore, it is likely that pre-mRNA splicing occurs in close proximity to the sites of transcription in both mammalian cells and amphibian germinal vesicles. In amphibian germinal vesicles anti-spliceosome antibodies also stain large extrachromosomal particles designated snurposomes (Wu et al. 1991). Snurposomes have been divided into three classes, designated $A, B$, and $C$. The A snurposomes appear to contain exclusively $\mathrm{U} 1$ snRNPs, the B snurposomes contain U1, U2, U4, U5, and
U6, as well as SC-35, and the C snurposomes consist of an aggregate of B snurposomes (Wu et al. 1991). While B snurposomes may be equivalent to clusters of interchromatin granules, counterparts for $\mathrm{A}$ and $\mathrm{C}$ snurposomes in mammalian cells have not been identified thus far.

In summary, we have observed the localization and nuclear association of nascent c-fos RNA transcripts in the cell nucleus. The RNA transcripts appear to be distributed in a path that extends to the nuclear membrane. Such a distribution represents the pathway by which the c-fos pre-mRNA is processed and transported through the nucleus. Most interestingly, a portion of this path is closely associated with nuclear speckles that contain pre-mRNA splicing factors. These results suggest that the sites of interaction between the c-fos RNA transcripts and the speckles are the sites where the c-fos pre-mRNA is spliced. The vectorial transport of c-fos RNA transcripts toward the nuclear envelope indicates a highly organized and regulated means of transport of mRNA through the nucleus to the nuclear pores.

\section{Materials and methods}

Probes and nick translation

p302-356 pBS - - , a 7.5-kb plasmid that contains a 4.4-kb fragment of mouse c-fos genomic sequence (Miller et al. 1984), was generously provided by Dr. Michael Gilman, Cold Spring Harbor Laboratory. The 4.4-kb fragment includes the $3^{\prime}-$ and $5^{\prime}-$ flanking sequences and the entire coding region of the mouse c-fos gene. The gene encodes a $3.5-\mathrm{kb}$ pre-mRNA that is later spliced into a $2.2-\mathrm{kb}$ mRNA. The first intron of $\mathrm{c}$-fos was subcloned by PCR into a pGEM-4Z vector (Promega) at the BamHI site between the Sp6 and T7 promoters. These two plasmids were nick-translated in the presence of either biotin-11-dUTP (Sigma) or digoxigenin-11-dUTP (Boehringer Mannheim) to generate labeled DNA probes. The DNase concentration and the duration of the nick translation reaction were adjusted so that the probe fragment size was $100-300 \mathrm{bp}$ after the nick translation. The fragment size of the probe was monitored by agarose gel electrophoresis. Biotin incorporation was detected by alkaline agarose gel electrophoresis. DNA was transferred to nitrocellulose filters and visualized by using streptavidin and biotinylated alkaline phosphatase (BRL).

\section{Cell culture}

NIH-3T3 cells were grown on coverslips in 35-mm Petri dishes in Dulbecco's modified Eagle medium (DMEM) supplemented with $10 \%$ FBS. To prepare cells for in situ hybridization, cells were grown for 2 days to $\sim 60 \%$ confluency. Cells were then synchronized to $G_{0}$ by complete deprivation of serum in the growth medium for $24 \mathrm{hr}$. At $15 \mathrm{~min}$ prior to the fixation of cells, or at the time indicated in the text, cells were stimulated by DMEM with $20 \% \mathrm{FBS}$ and $20 \mu \mathrm{g} / \mathrm{ml}$ of anisomysin, a protein synthesis inhibitor, which can enhance c-fos transcription (Greenberg et al. 1986). For inhibition of transcription, cells were incubated in $10 \mu \mathrm{g} / \mathrm{ml}$ of actinomycin D for $2 \mathrm{hr}$ before fixation.

\section{Fixation}

Cells were fixed in $3 \%$ paraformaldehyde in PBS (pH 7.3) containing $5 \mathrm{mM} \mathrm{MgCl}_{2}$ for $15 \mathrm{~min}$ at $20^{\circ} \mathrm{C}$. Cells were then washed three times (for $10 \mathrm{~min}$ each) in $0.3 \mathrm{M}$ glycine in $\mathrm{PBS}$ to quench 
any free aldehydes. Cells were permeabilized with $0.5 \%$ Triton-X 100 in PBS for 5 min on ice and washed twice in PBS (10 min each), followed by washes with $2 \times$ SSC and $2 \times$ SSC plus $50 \%$ formamide for 10 min each. For RNase A and DNase I digestion, cells were incubated with either $100 \mu \mathrm{g} / \mathrm{ml}$ of RNase or $5 \mathrm{U} / 30 \mu \mathrm{l}$ of RNase-free DNase (Boehringer Mannheim) at $37^{\circ} \mathrm{C}$ for $1-2 \mathrm{hr}$ and washed in PBS prior to hybridization.

\section{Hybridization}

The in situ hybridization protocol was modified from a procedure developed by Singer et al. (1986). The labeled probes, ranging in concentration from 100 to $500 \mathrm{ng}$, were dried in a Speedvac, together with $20 \mu \mathrm{g}$ of Escherichia coli tRNA and $5 \mu \mathrm{g}$ of sheared salmon sperm DNA. The probes were resuspended in 10 $\mu l$ of deionized formamide, heat-denatured at $75^{\circ} \mathrm{C}$ for $10 \mathrm{~min}$, and immediately placed on ice. The final hybridization mixture of $20 \mu \mathrm{l} /$ coverslip contained $0.6 \mathrm{MNaCl}, 0.01 \mathrm{M}$ Tris- $\mathrm{HCl} / \mathrm{pH}$ 7.2), $0.001 \mathrm{M}$ EDTA, 5\% dextran sulfate, $1 \times$ Denhardt's buffer, $50 \%$ formamide ( $\mathrm{vol} / \mathrm{vol}$ ), denatured probe DNA, tRNA, and sheared salmon sperm DNA. The hybridization mixture was applied to the coverslip, which was inverted onto an RNase-free baked glass slide and sealed with rubber cement. The hybridizations were carried out at $42^{\circ} \mathrm{C}$ in a humidified chamber overnight. After hybridization cells were washed three times (15 min each) in $2 \times \mathrm{SSC}$ at $45^{\circ} \mathrm{C}$ and once for $15 \mathrm{~min}$ in $1 \times \mathrm{SSC}$ at $20^{\circ} \mathrm{C}$.

\section{Signal detection}

Hybridization with biotinylated DNA probes was detected by FITC-conjugated avidin DCS (Vector). Samples were incubated at $20^{\circ} \mathrm{C}$ with $2 \mu \mathrm{g} / \mathrm{ml}$ of FITC-conjugated avidin in PBS containing $0.5 \% \mathrm{BSA}$ for $30 \mathrm{~min}$. Cells were then washed three times (10 min each) in $4 \times$ SSC with $0.1 \%$ Tween 20 . To visualize total DNA, cells were stained with DAPI at a concentration of 1 $\mathrm{mg} / \mathrm{ml}$ for $2 \mathrm{~min}$ and rinsed with PBS before mounting. Hybridization with digoxigenin-labeled probes was detected by rhodamine-conjugated sheep anti-digoxigenin antibodies (Fab fragments, Boehringer Mannheim). Cells were incubated with the antibody at a $1: 5$ dilution for $1 \mathrm{hr}$ at $20^{\circ} \mathrm{C}$ followed by three washes in PBS (10 min each). Finally, the coverslips were mounted onto glass slides in mounting medium containing $90 \%$ glycerol in $0.2 \mathrm{M}$ Tris-base $(\mathrm{pH} 8.0)$ with $3.5 \% n$-propyl gallate (Sigma) as an antifading agent. Cells were examined with a Nikon FXA microscope equipped with epifluorescence and differential interference contrast optics or with a Zeiss confocal laser scanning microscope as described below.

\section{Immunolabeling}

After detection of the hybridization signal by FITC-conjugated avidin, cells were washed three times (10 min each) in PBS containing $1 \%$ normal goat serum. Cells were then incubated with anti-SC-35 monoclonal antibody (Fu and Maniatis 1990) at a dilution of $1: 50$ for $1 \mathrm{hr}$ and rinsed in PBS containing $1 \%$ normal goat serum (NGS) three times (10 min each). Cells were then incubated with Texas Red-conjugated goat anti-mouse antibody at a dilution of $1: 20$ for $1 \mathrm{hr}$, followed by three washes in PBS for $10 \mathrm{~min}$ each. The coverslips were mounted and observed with a Nikon FXA microscope as described above or with a Zeiss confocal laser scanning microscope as described below.

\section{Confocal laser scanning microscopy}

Cells were hybridized and immunolabeled as described above and examined with a Zeiss confocal laser scanning microscope equipped with a $63 \mathrm{X} / 1.4$ N.A. oil imersion lens. Optical sections of $0.25 \mu \mathrm{m}$ were observed by using an Argon laser $(\lambda=488$ $\mathrm{nm})$ to view FITC fluorescence and a HeNe laser $(\lambda=543)$ to observe Texas Red fluorescence. Optical sections spanning the depth of the nucleus were reconstructed by using an INDEC image analysis system, which was linked directly to the confocal microscope. Fluorescently labeled $6-\mu \mathrm{m}$ spheres were optically sectioned and $\mathrm{X}-\mathrm{Z}$-scanned to confirm that stretching in the $Z$-axis was not occurring in our preparations. By using the program package MicroVoxel (INDEC), images were reconstructed every $10^{\circ}$ through $360^{\circ}$ and viewed as rotations. For double-labeling, reconstructions of hybridization and antibody staining were assigned different gray levels, fused, and pseudocolored on the basis of gray level. Images were recorded by using a Sony UP5000 color video printer or a Matrix MultiColor image recording system.

\section{Pre-embedding in situ hybridization electron microscopy}

Following hybridization, as described above, cells were incubated with $2 \mu \mathrm{g} / \mathrm{ml}$ of horseradish peroxidase-conjugated streptavidin in PBS for $1 \mathrm{hr}$ and washed three times in PBS $/ 10$ min each). Cells were postfixed in $2 \%$ glutaraldehyde in PBS for $20 \mathrm{~min}$ at room temperature, washed twice in PBS, and once in $0.05 \mathrm{~m}$ Tris buffer ( $\mathrm{pH} \mathrm{7.6)}$ for $10 \mathrm{~min}$. The peroxidase reaction product was developed by incubation in $0.5 \%$ diaminobenzidine containing $0.01 \% \mathrm{H}_{2} \mathrm{O}_{2}$ for $5 \mathrm{~min}$ at $20^{\circ} \mathrm{C}$. Cells were then fixed in $1 \%$ osmium tetroxide in $0.1 \mathrm{M}$ cacodylate buffer $(\mathrm{pH} 7.3)$ and prepared for electron microscopy as described previously (Spector and Smith 1986). Thick sections $(1 \mu \mathrm{m})$ were examined with an AEI high-voltage transmission electron microscope (HVEM) (Wadsworth Center, Albany, NY) operated at $600 \mathrm{kV}$. Images were high-pass-filtered and contrast-enhanced by using STERECON at the Albany HVEM laboratory.

\section{Acknowledgments}

The excellent electron microscopic technical assistance of Robert Derby is greatly appreciated. We are grateful to Dr. David Ward (Yale University, School of Medicine) for many helpful discussions on in situ hybridization. We thank Dr. Michael Gilman (Cold Spring Harbor Laboratory) for providing us with a mouse c-fos clone and Drs. Xiang-Dong Fu and Tom Maniatis (Harvard University) for providing us with anti-SC-35 antibodies. We appreciate the helpful comments of Michael Gilman, Scott Henderson, Adrian Krainer, Ray O'Keefe, Tom Maniatis, Rich Roberts, and Jim Watson. The high-voltage electron microscopy was performed at the Wadsworth Center's Biological Microscopy and Image Reconstruction Facility (Albany, NY), a National Biotechnological Resource supported by Biotechnological Resource grant RR01219 from the National Center for Research Resources, Department of Health and Human Services/ U.S. Public Health Service. We particularly appreciate the assistance of Dr. Conly Rieder and Mr. Richard Cole at the Wadsworth Center. This study was supported by grants from the American Cancer Society (NP-619A) and the National Institutes of Health (GM42694 and 5P30 CA45508-03) to D.L.S.

The publication costs of this article were defrayed in part by payment of page charges. This article must therefore be hereby marked "advertisement" in accordance with 18 USC section 1734 solely to indicate this fact.

\section{References}

Agutter, P.S. 1988. Nucleo-cytoplasmic transport of mRNA: Its relationship to RNA metabolism, subcellular structure and 
other nucleocytoplasmic exchanges. Prog. Mol. Subcell. Biol. 10: 15-96.

Bachellerie, J.-P., E. Puvion, and J.-P. Zalta. 1975. Ultrastructural organization and biochemical characterization of chromatin RNA protein complexes isolated from mammalian cell nuclei. Eur. J. Biochem. 58: 327-337.

Berezney, R. 1984. Organization and functions of the nuclear matrix. In Chromosomal nonhistone proteins Vol. IV. Structural associations (ed. L.S. Hnilica), pp. 119-180. CRC Press, Boca Raton, FL..

Beyer, A.L. and Y.N. Osheim. 1988. Splice site selection, rate of splicing, and alternative splicing on nascent transcripts. Genes \& Dev. 2: 754-765.

Bindereif, A. and M. Green. 1990. Identification and functional analysis of mammalian splicing factors. In Genetic engineering (ed. J.K. Setlow), vol. 12, pp. 201-224. Plenum Press, New York.

Blobel, G. 1985. Gene gating: A hypothesis. Proc. Natl. Acad. Sci. 82: 8527-8529.

Bravo, R., J. Burckhardt, T. Curran, and R. Muller. 1986. Expression of c-fos in NIH-3T3 cells is very low but inducible throughout the cell cycle. EMBO J. 5: 695-700.

Carmo-Fonseca, M., D. Tollervey, S.M.L. Barabino, A. Merdes, C. Brunner, P.D. Zamore, M.R. Green, E. Hurt, and A.I. Lamond. 1991a. Mammalian nuclei contain foci which are highly enriched in components of the pre-mRNA splicing machinery. $E M B O$ /. 10: 195-206.

Carmo-Fonseca, M., R. Pepperkok, B.S. Sproat, W. Ansorge, M. Swanson, and A.I. Lamond. 1991b. In vivo detection of snRNP-rich organelles in the nuclei of mammalian cells. EMBO I. 10: 1863-1873.

Ciejek, E.M., J.L. Nordstrom, M.-J. Tsai, and B.W. O'Malley. 1982. Ribonucleic acid precursors are associated with the chick oviduct nuclear matrix. Biochemistry 21: 4945-4953.

Curran, T. and B.R. Franza. 1988. Fos and Jun: the AP-1 connectiuon. Cell 55: 395-397.

Curran, T., G. Peters, C. Van Beveren, N.M. Teich, and I.M. Verma. 1982. FBJ murine osteosarcoma virus: Identification and molecular cloning of biologically active proviral DNA. . Virol, 44: 674-682.

Fakan, S. and W. Bernhard. 1971. Localisation of rapidly and slowly labelled nuclear RNA as visualized by high resolution autoradiography. Exp. Cell Res. 67: 129-141.

- 1973. Nuclear labelling after prolonged ${ }^{3} \mathrm{H}$-uridine incorporation as visualized by high resolution autoradiography. Exp. Cell Res. 79: 431-444.

Fakan, S. and P. Nobis. 1978. Ultrastructural localization of transcription sites and of RNA distribution during the cell cycle of synchronized CHO cells. Exp. Cell Res. 113: 327337.

Fakan, S., E. Puvion, and G. Spohr. 1976. Localization and characterization of newly synthesized nuclear RNA in isolated rat hepatocytes. Exp. Cell Res. 99: 155-164.

Fakan, S., G. Leser, and T.E. Martin. 1984. Ultrastructural distribution of nuclear ribonucleoproteins as visualized by immunocytochemistry on thin sections. I. Cell Biol. 98: 358363.

-1986. Immunoelectron microscope visualization of nuclear ribonucleoprotein antigens within spread transcription complexes. J. Cell Biol. 103: 1153-1157.

Feldherr, C.M. and S.I. Dworetzky. 1988. The pore complex in nucleocytoplasmic exchange. In Nucleocytoplasmic transport (ed. R. Peters), pp. 127-144, Academic Press, New York.

Fu, X-D. and T. Maniatis. 1990. Factor required for mammalian spliceosome assembly is localized to discrete regions in the nucleus. Nature 343: 437-441.
Gall, J.G. 1991. Organelle assembly and function in the amphibian germinal vesicle. In Advances in developmental biochemistry (ed. P. Wassarman|, vol. 1, pp. 1-29. J.A.I. Press, Greenwich, Connecticut.

Gall, J.G. and H.G. Callan. 1989. The sphere organelle contains small nuclear ribonucleoproteins. Proc. Natl. Acad. Sci. 86: 6635-6639.

Greenberg, M.E. and E.B. Ziff. 1984. Stimulation of 3T3 cells induces transcription of the c-fos proto-oncogene. Nature 311: 433-438.

Greenberg, M.E., A.L. Hermanowski, and E.B. Ziff. 1986. Effect of protein synthesis inhibitors on growth factor activation of c-fos, c-myc, and actin gene expression. Mol. Cell Biol. 6: $1050-1057$.

Habets, W.J., M.H. Hoet, B.A.W. De Jong, A. Van Der Kemp, and W.J. Van Venrooij. 1989. Mapping of B cell epitopes on small nuclear ribonucleoproteins that react with human autoantibodies as well as with experimentally induced mouse monoclonal antibodies. I. Immunol. 143: 2560-2566.

Huang, S. and D.L. Spector. 1991. U1 and U2 snRNAs are present in nuclear speckles. Proc. Natl. Acad. Sci. (in press).

Krainer, A. and T. Maniatis. 1988. RNA splicing. In Frontiers in molecular biology: Transcription and splicing (ed. B.D. Hames and D.M. Glover), pp. 131-296. IRL Press, Oxford/ Washington D.C.

Kruijer, W., J.A. Cooper, T. Hunter, and I.M. Verma. 1984. Platelet-derived growth factor induces rapid but transient expression of the c-fos gene and protein. Nature 312: 711-716.

Lawrence, J.B., R.H. Singer, and L.M. Marselle. 1989. Highly localized tracks of specific transcripts within interphase nuclei visualized by in situ hybridization. Cell 57: 493-502.

LeStourgeon, W.M. 1978. The occurrence of contractile proteins in nuclei and their possible functions. In The cell nucleus, Vol. VI (ed. H. Busch), pp. 305-326. Academic Press, New York.

Mariman, E.C., C.A.G. van Eekelen, R.J. Reinders, A.J.M. Berns, and W.J. van Venrooij. 1982. Adenoviral heterogeneous nuclear RNA is associated with the host nuclear matrix during splicing. I. Mol. Biol. 154: 103-119.

Miller, A.D., T. Curran, and I.M. Verma. 1984. c-fos protein can induce cellular transformation: A novel mechanism of activation of a cellular oncogene. Cell 36: $51-60$.

Muller, R., R.Bravo, and J. Burckhardt. 1984. Induction of c-fos gene and protein by growth factors procedes activation of c-myc. Nature 312: 716-720.

Nyman, U., H. Hallman, G. Hadlaczky, I. Pettersson, G. Sharp, and N.R. Ringertz. 1986. Intranuclear localization of snRNP antigens. I. Cell Biol. 102: 137-144.

O'Farrell, P.H., B.A. Edgar, D. Lakich, and C.F. Lehner. 1989. Directing cell division during development. Science 246: 635-640.

Puvion, E. and W. Bernhard. 1975. Ribonucleoprotein components in liver cell nuclei as visualized by cryoultramicrotomy. J. Cell Biol. 67: 200-214.

Puvion, E., A. Viron, C. Assens, E.H. Leduc, and P. Jeanteur. 1984. Immunocytochemical identification of nuclear structures containing snRNPs in isolated rat liver cells. I. Ultrastruct. Res. 87: 180-189.

Reuter, R., B. Appel, P. Bringmann, J. Rinke, and R. Luhrmann. 1984. $5^{\prime}$-Terminal caps of snRNAs are reactive with antibodies specific for 2,2,7-trimethylguanosine in whole cells and nuclear matrics. Exp. Cell Res. 154: 548-560.

Rubin, A.L., A. Yao, and H. Rubin. 1990. Relation of spontaneous transformation in cell culture to adaptive growth and clonal heterogeneity. Proc. Natl. Acad. Sci. 87: 482-486.

Sass, H. and T. Pederson. 1984. Transcription-dependent local- 
ization of $\mathrm{U} 1$ and $\mathrm{U} 2$ small nuclear ribonucleoproteins at major sites of gene activity in polytene chromosomes. J. Mol. Biol. 180: 911-926.

Schindler, M. and L.-W. Jiang. 1986. Nuclear actin and myosin as control elements in nucleocytoplasmic transport. $J$. Cell Biol. 102: 859-862.

Sheng, M. and M.E. Greenberg. 1990. The regulation and function of c-fos and other immediate early genes in the nervous system. Neuron 4: 477-485.

Singer, R.H., J.B. Lawrence, and C. Villnave. 1986. Optimization of in situ hybridization using isotopic and nonisotopic detection methods. Biotechniques 4: 230-250.

Smetana, K., W.J. Steele, and H. Busch. 1963. A nuclear ribonucleoprotein network. Exp. Cell Res. 31: 198-201.

Spector, D.L. 1984. Colocalization of U1 and U2 small nuclear RNPs by immunocytochemistry. Biol. Cell. 51: 109-112.

. 1990. Higher order nuclear organization: Three-dimentional distribution of small nuclear ribonucleoprotein particles. Proc. Natl. Acad. Sci. 87: 147-151.

Spector, D.L. and H. C. Smith. 1986. Redistribution of UsnRNPs during mitosis. Exp. Cell Res. 163: 87-94.

Spector, D.L., W.H. Schrier, and H. Busch. 1983. Immunoelectron microscopic localization of snRNPs. Biol. Cell 49: 110.

Spector, D.L., X.-D. Fu, and T. Maniatis. 1991. Associations between distinct pre-mRNA splicing components and the cell nucleus. $E M B O J_{.}$, in press.

Steitz, J.A., D.L. Black, V. Gerke, K.A. Parker, A. Kramer, D. Frendewey, and W. Keller. 1988. Functions of the abundant U-snRNPS. In Structure and function of major and minor small nuclear ribonucleoprotein particles (ed. M.L. Birnstiel), pp. 115-154. Springer Verlag, Berlin/Heidelberg.

Verheijen, R., H. Kuijpers, P. Vooijs, W. van Venrooij, and F. Ramaekers. 1986. Distribution of the 70k Ul RNA-associated protein during interphase and mitosis. Correlation with other U RNP particles and proteins of the nuclear matrix. $J$. Cell Sci. 86: 173-190.

Vogelstein, B. and B.F. Hunt. 1982. A subset of small nuclear ribonucleoprotein particle antigens is a component of the nuclear matrix. Biochem. Biophys. Res. Comm. 105: 1224 1232.

Wang, I., L.-G. Cao, Y.-L. Wang, and T. Pederson. 1991. Localization of pre-messenger RNA at discrete nuclear sites. Proc. Nat1. Acad. Sci. 88: 7391-7395.

Wu, Z., C. Murphy, H.G. Callan, and J.G. Gall. 1991. Small nuclear ribonucleoproteins and heterogeneous nuclear ribonucleoproteins in the amphibian germinal vesicle: Loops, spheres, and snurposomes. J. Cell Biol. 113: 465-483.

Xing, Y. and J.B. Lawrence. 1991. Preservation of specific RNA distribution within the chromatin-depleted nuclear substructure demonstrated by in situ hybridization coupled with biochemical fractionation. J. Cell Biol. 112: 1055-1063.

Zamore, P.D. and M.R. Green. 1991. Biochemical characterization of U2 snRNP auxiliary factor: An essential pre-mRNA splicing factor with a novel intranuclear distribution. $E M B O$ I. 10: 207-214.

Zeitlin, S., R.C. Wilson, and A. Efstratiadis. 1989. Autonomous splicing and complementation of in vivo-assembled spliceosomes. J. Cell Biol. 108: 765-777. 


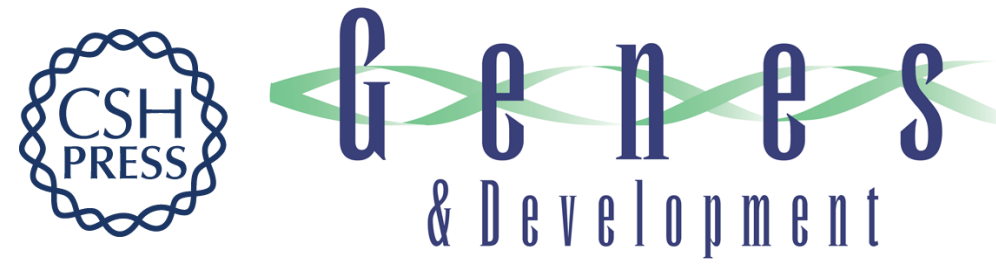

\section{Nascent pre-mRNA transcripts are associated with nuclear regions enriched in splicing factors.}

S Huang and D L Spector

Genes Dev. 1991, 5:

Access the most recent version at doi:10.1101/gad.5.12a.2288

References This article cites 48 articles, 19 of which can be accessed free at:

http://genesdev.cshlp.org/content/5/12a/2288.full.html\#ref-list-1

License

Email Alerting

Service

Receive free email alerts when new articles cite this article - sign up in the box at the top right corner of the article or click here.

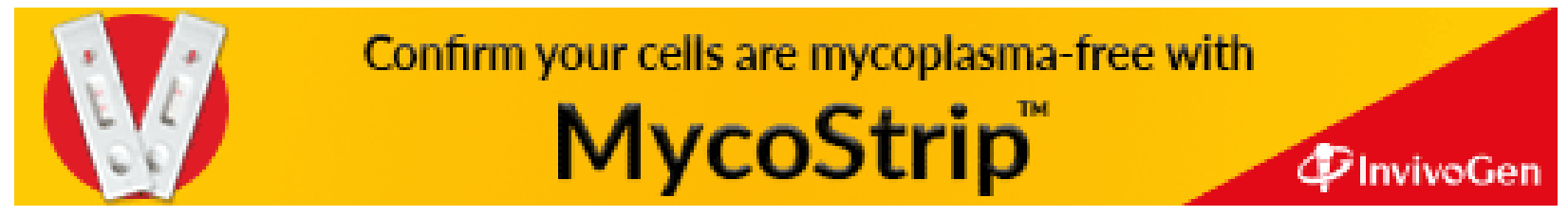

